\author{
BULETINUL INSTITUTULUI POLITEHNIC DIN IAŞI \\ Publicat de \\ Universitatea Tehnică „Gheorghe Asachi” din Iaşi \\ Volumul 67 (71), Numărul 3, 2021 \\ Secţia \\ CONSTRUCȚII DE MAȘINI \\ DOI:10.2478/bipcm-2021-0013 \\ sciendo
}

\title{
SURVEY ON REGENERATIVE BRAKING IN ELECTRICAL AND HYBRID VEHICLES
}

\author{
BY
}

\section{VICTOR STAJILOV* and CARMEN BUJOREANU}

"Gheorghe Asachi" Technical University of Iaşi,

Faculty of Mechanical Engineering, Iaşi, Romania

Received: March 26, 2021

Accepted for publication: June 25, 2021

\begin{abstract}
Strict pollution norms make car's manufacturers to promote electrical and hybrid vehicles (EVs and HEVs). Recuperation system that can capture about $8-25 \%$ of the energy is represented by the regenerative brakes, it converts losses of kinetic energy of the car during braking in form of heat to electrical or chemical energy. Regenerative brakes can provide a good increase in car's autonomy, especially in city driving cycles with high frequency of braking. Also, they reduce friction brakes wear and offer more precisely control of wheel braking torque. A survey in this paper presents basics, uses, types and braking strategies for existing regenerative braking systems with the purpose to identify and detail their limitations. Identifying key factors that have influence on system efficiency allows to elaborate optimizing techniques, strategies and algorithms, applied to existing systems in order to develop future concepts that will overcome current limitations.
\end{abstract}

Keywords: Regenerative brakes; electrical vehicles; generator; energy recuperation.

${ }^{*}$ Corresponding author; e-mail: victor.stjlv@gmail.com

(C) 2021 Victor Stajilov et al.

This is an open access article licensed under the Creative Commons Attribution-NonCommercialNoDerivatives 4.0 International License (CC BY-NC-ND 4.0). 


\section{Introduction}

Pollution norms became more strictly each year and with the increasing number of automobiles the electrical vehicles (EV) and hybrid vehicles (HEV) get more popular. Biggest car manufacturers invest more money in this technology and almost all of them already have HEV and EV models. With an electrical motor as main propulsion the energy is recovered by switching to generator mode.

In combustion engines vehicles, while braking, kinetic energy of moving car is transformed to heat which is dissipated in the environment. Also, hydraulic brake systems are not pollution free because of possible leakage and wear resulting from braking pads.

Regenerative brakes transform part of car's kinetic energy in electrical energy (super capacitor), chemical energy (battery), mechanical energy (flywheel), pneumatic or hydraulic energy (compressed fluids).

- to chemical energy
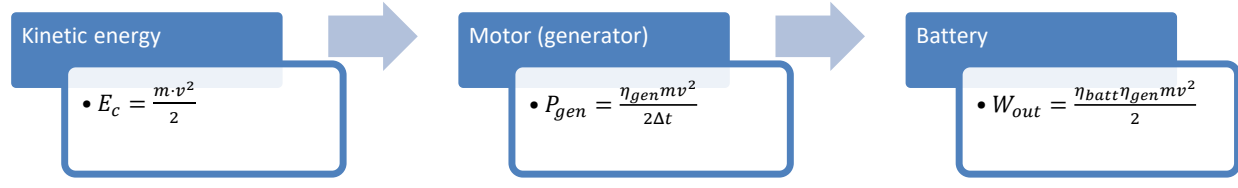

- to electrical energy
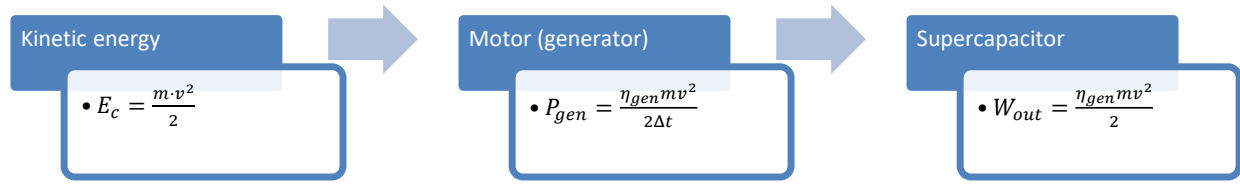

- to mechanical energy
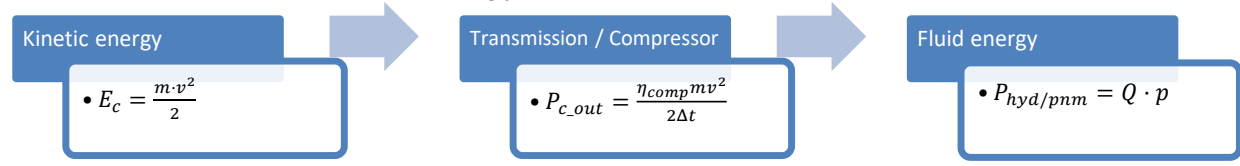

- to pneumatic/hydraulic energy
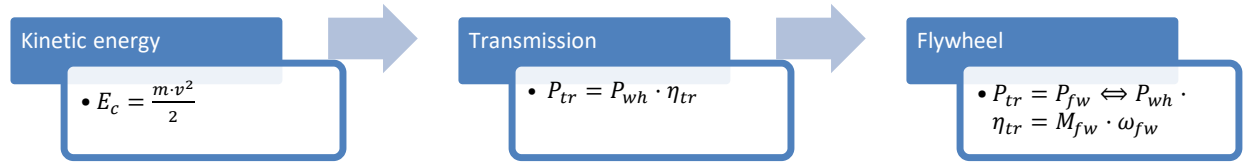
Generator principle (permanent magnet synchronous generator excitation field is generated by a permanent magnet, instead of a coil), magnetic field is generated through a shaft on which is mounted a permanent magnet mechanism and the current is induced into the stationary armature. Majority designs imply that rotating assembly in the center of the generator ("rotor") contains the magnet, and the "stator" is the stationary armature that is electrically connected to a load (Alexandra von Maier, 2006).
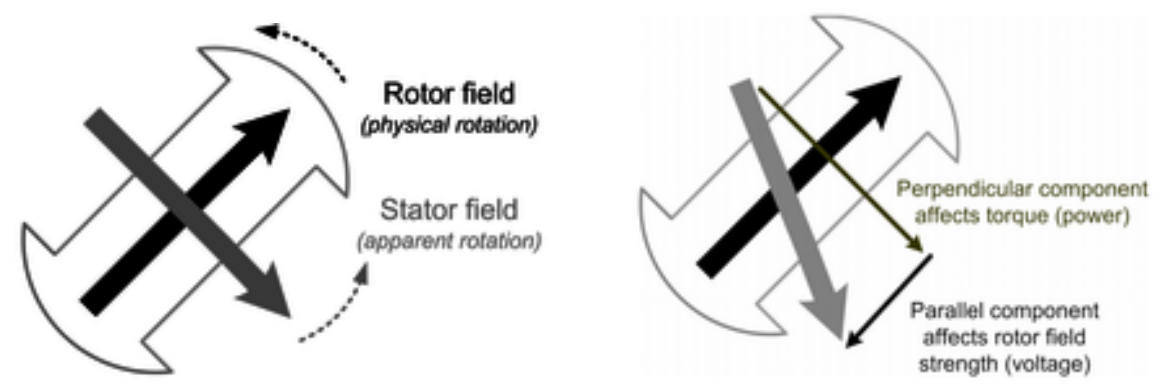

Fig. 1 - Schematic diagram of rotor field rotation in Permanent Magnet Synchronous Generator (Alexandra von Maier, 2006).

Mechanical power in the rotor depends on torque and rotational speed: $P_{m}=T_{m} \cdot \omega$. Power produced by generator has two components: active and reactive: $P+j Q=S$ (apparent power). Figs. 2 and 3 include graphical representations of $\theta$ angle (angle between the voltage $V_{a}$ and the current in the load $I_{a}$ ) and $\delta$ angle (angle between the voltage of the generator $E_{i}$ and the voltage of the load). The last can be used to determine the real and reactive power output from the generator, Eqs. (2) and (3).

$$
\begin{gathered}
I_{a}=\frac{\left|E_{i}\right| \angle \delta-\left|V_{t}\right|}{j X_{d}} \\
S=P+j Q=V_{t} I^{*}=\frac{\left|V_{t}\right|\left|E_{i}\right| \angle(-\delta)-\left|V_{t}\right|^{2}}{-j X_{d}} \\
=\frac{\left|V_{t}\right|\left|E_{i}\right|(\cos \delta-j \cdot \sin \delta)-\left|V_{t}\right|^{2}}{-j X_{d}} \\
I_{a}=\frac{\left|E_{i}\right| \angle \delta-\left|V_{t}\right|}{j X_{d}}
\end{gathered}
$$




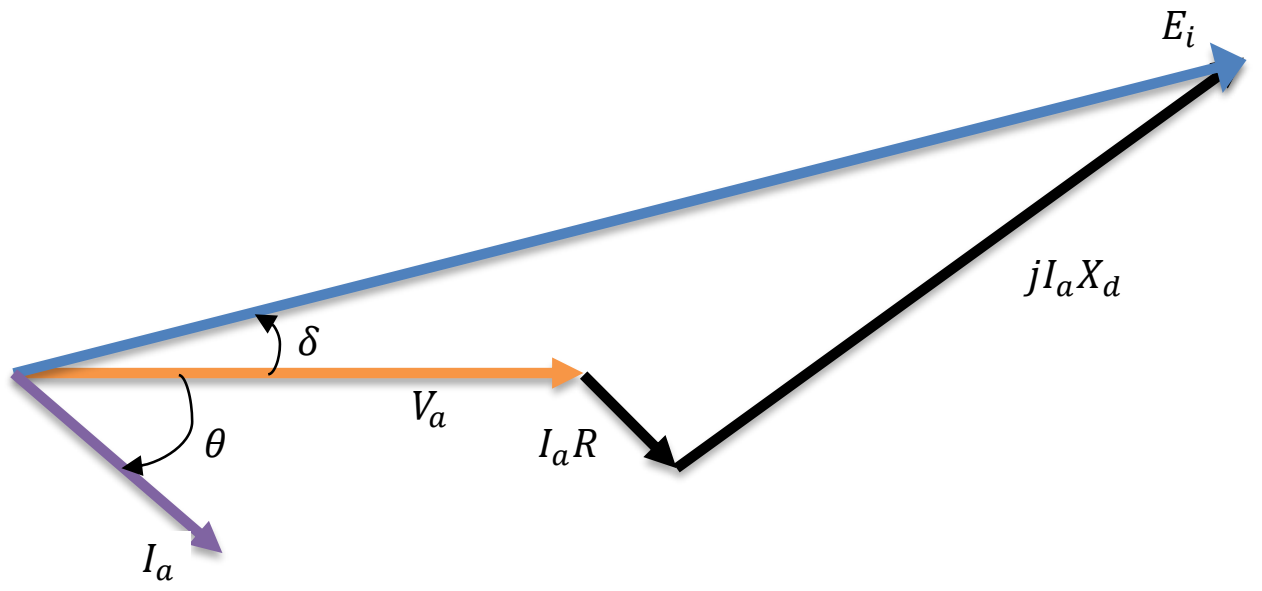

Fig. 2 - Vector representation of voltage in generator $E_{i}$, the voltage and the current of the load $V_{a}, I_{a}$ based on equations in (Stephen Champman, 2011).

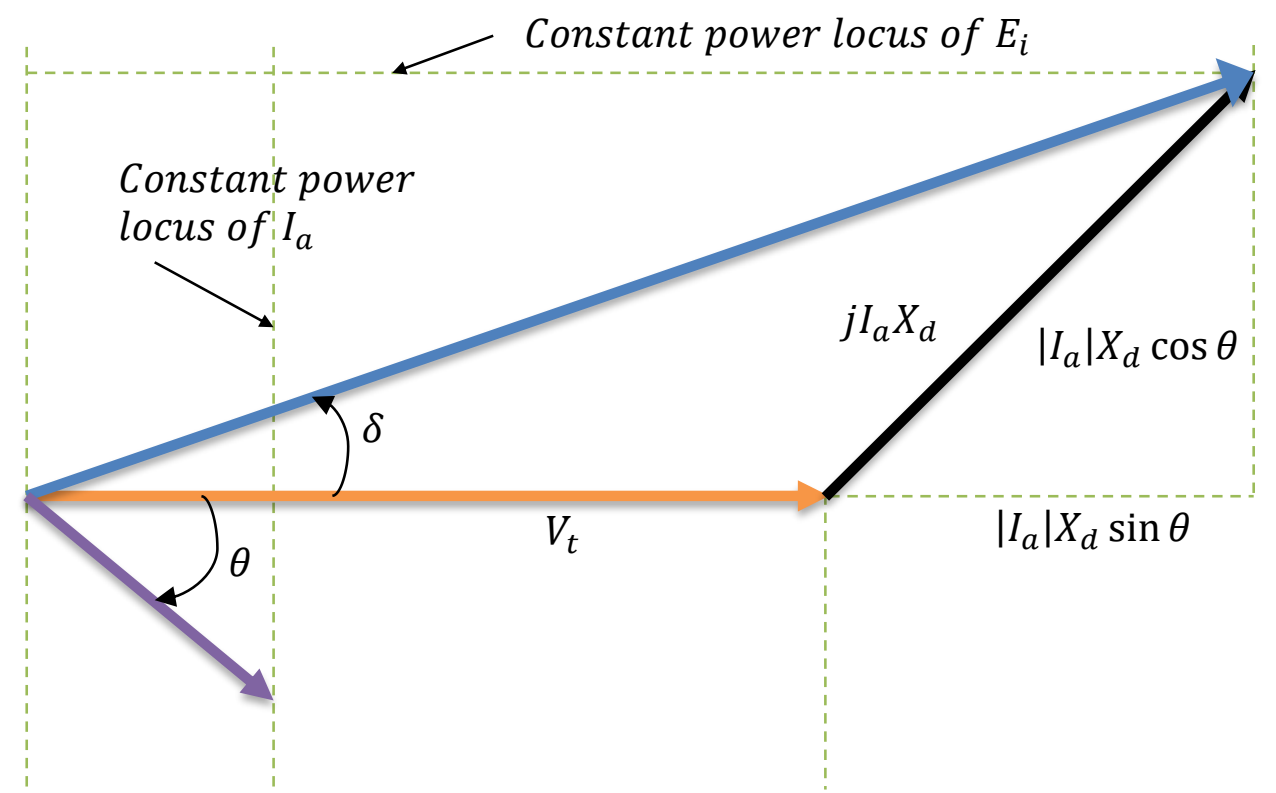

Fig 3 - Graphical representation of constant power, ignoring resistance, based on equations in (Stephen Champman, 2011). 


\section{Advantages. Disadvantages. Drawbacks. Challenges. Limitations}

Regenerative brake's main advantage is recovering and reusage of a part of kinetic energy of the car during deceleration, this implies reduced wear of mechanical (frictional) brakes and prolonged autonomy. Regenerative brakes systems with an electrical motor is preferred because same motors used for propulsion can be also used for braking, but such systems come with some disadvantages:

- mechanical (frictional) brakes also required, electrical motor cannot assure braking until standstill;

- more complex motor/generator control algorithms/strategies;

- artificial brake pedal feeling should be induced;

Limitations that reduces regenerative brakes with generators efficiency:

- cannot assure brake power at low speeds $(<5-10 \mathrm{~km} / \mathrm{h})$;

- limited brake power at high speed due to battery safety (state of charge indicator of the battery);

- brake distribution to ensure car stability;

- efficiency strictly depending on driving style;

- electrical - chemical conversion efficiency loss, in case of battery;

- lower efficiency in emergency braking compared to frictional brakes.

- cannot ensure emergency brake

\section{Brake Strategies}

Cooperation between friction brakes and regenerative brakes can impact significantly efficiency of recuperation and brakes performance (Fig. 4).

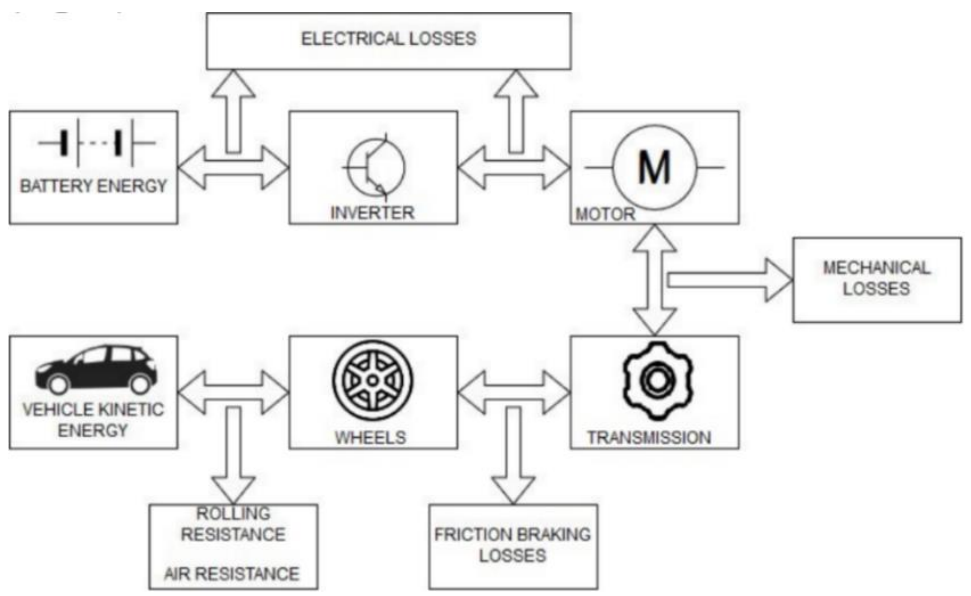

Fig. 4 - Energy flows in an electric vehicle (Krzysztof Popiołek, 2019, Fig. 1). 
One of the often-met classification of strategies (Xiao et al., 2017; Ehsani et al., 2005) assume parallel and series strategies. In parallel strategies, friction brakes and regenerative brakes cooperate together (brakes simultaneously, but variable ratios) to meet required deceleration. Series strategies presume the use of regeneration brake only until it reaches its maximum braking force and the rest of needed braking force is covered by frictional brakes.

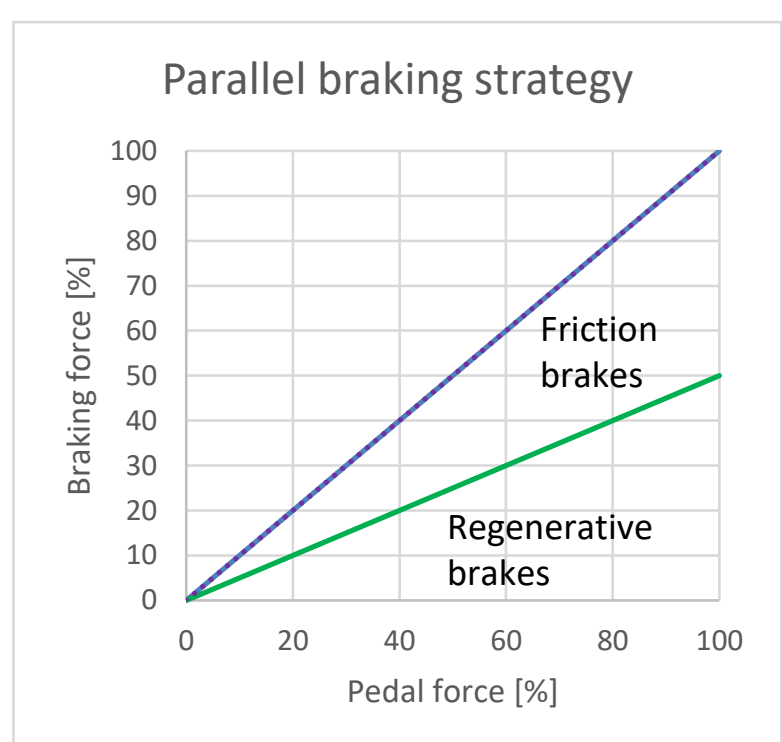

Fig. 5 - Parallel braking strategy, proposed in (Krzysztof Popiołek, 2019).

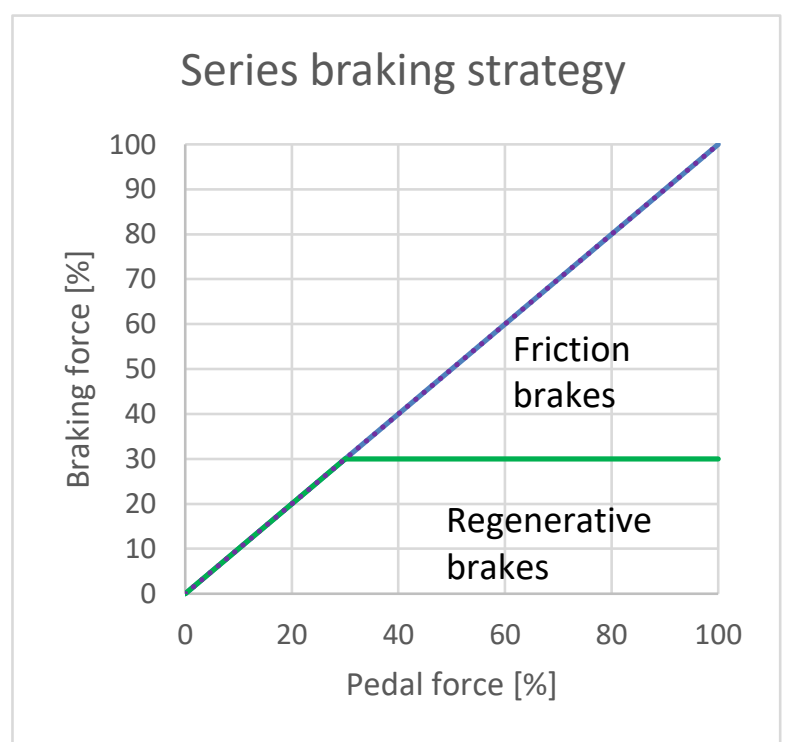

Fig. 6 - Series braking strategy, proposed in (Krzysztof Popiołek, 2019). 
Series braking offers better regenerative efficiency, as generator is used for a longer period of time, during low demanding deceleration (reducing speed at high speeds or moving in traffic jams). But controlling algorithm of such systems are more complex, an ahead planning should be done to choose optimal frictional brakes engagement. To ensure the almost ideal braking curve characteristic, good control of electrical machine is needed.

Parallel braking is easier to implement, as during entire braking process both of the brake systems (frictional and regenerative) are implied. The problem in this case is ratio distribution over braking process.

Figs. 5 and 6 present a general description for series and parallel strategies, it does not consider the car's drivetrain configuration. For the cars which have only one drive axle, the regenerative braking is not available on all the wheels, only for those that are connected to generator. In this case one axle will be equipped only with friction brakes, while the other could adopt series (Fig. 7 and Fig. 8) or parallel strategies (Xiao et al., 2017).

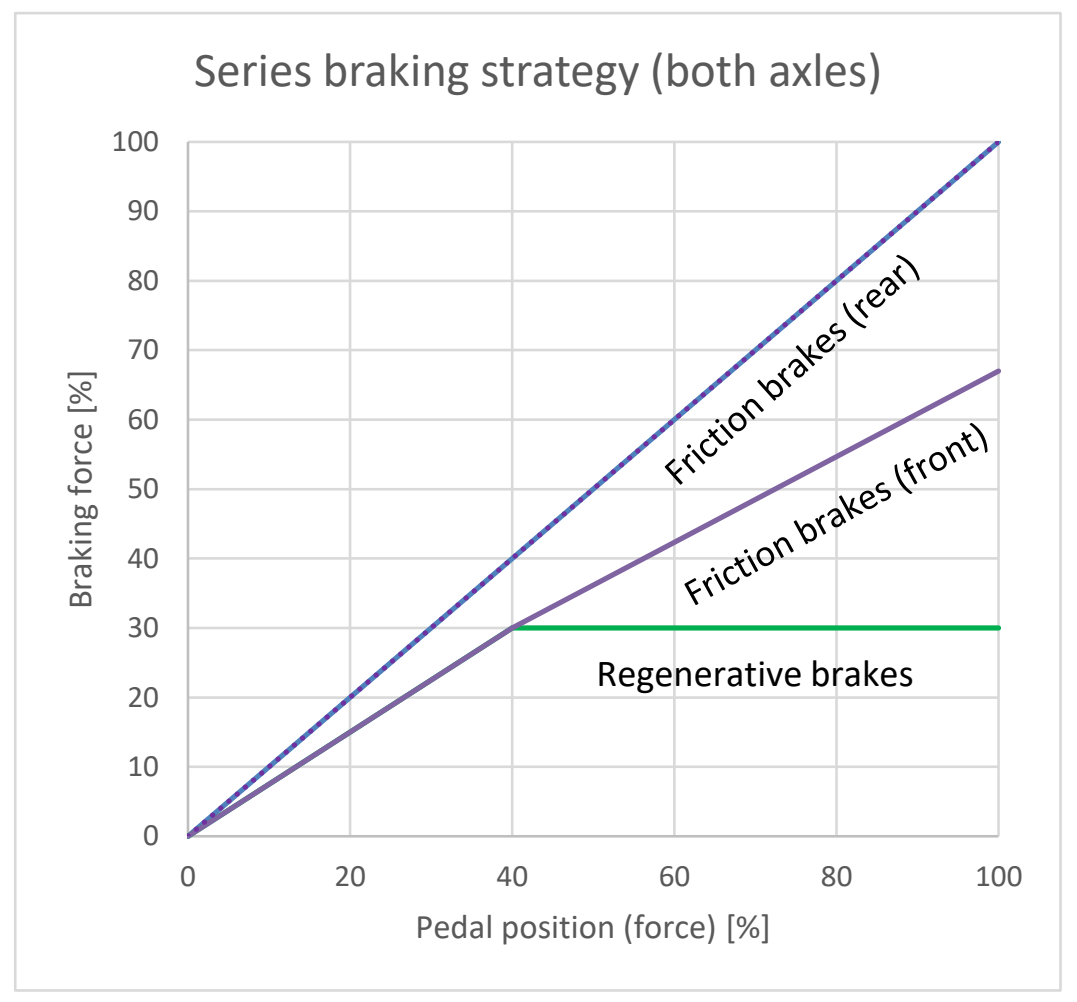

Fig 7 - Series strategy for regenerative brake (on front axle), simultaneously with friction brake on rear axle, proposed in (Xiao et al., 2017). 


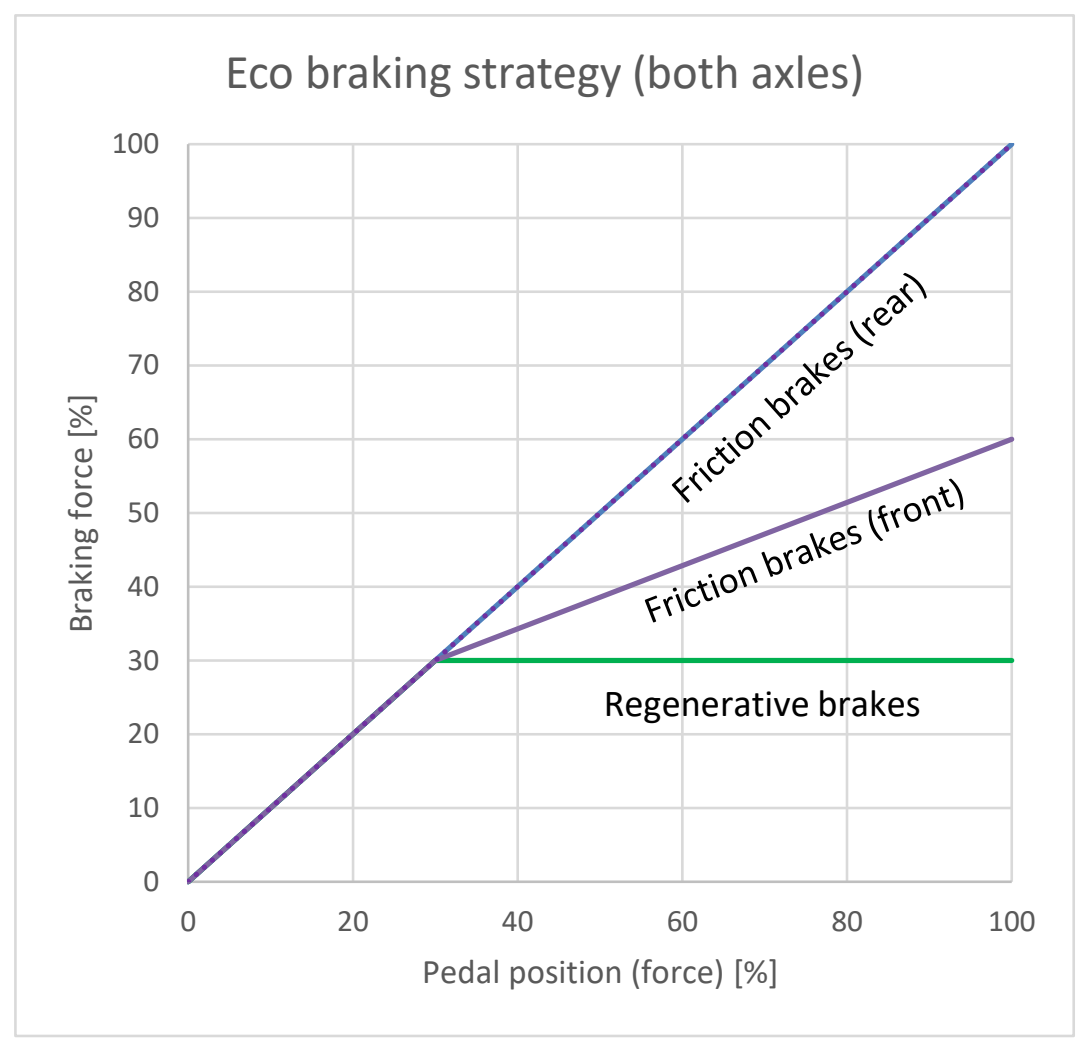

Fig. 8 - Eco strategy for regenerative brake (on front axle), simultaneously with friction brake on rear axle, proposed in (Xiao et al., 2017).

\section{Discussion}

- At very low speeds the electrical losses are bigger than the recovered energy. Also, it cannot be used to stop the car and emergency brakes because if rotor rotational speed became equal to zero, no more flux will be induced by rotor, which means that there is no brake torque generated. Brake torque depends on the magnetic flux generated by the stator, which is directly proportional to the derivative of the current in stator. The current in stator is a result of induced stator voltage by the rotor flux, the last strictly dependent on rotor rotational speed.

$$
T_{e}=-K \phi i_{a}
$$

From point of view of brake performance and recovered energy, regenerative braking can be used only for medium and high speed. 
- In case of the batteries, we mention two factors impact efficiency of regenerative brakes: electrical - chemical conversion and battery limitation (state of charge (SOC) and battery temperature). Batteries can be used only in the values of SOC 10\%-90\%; in this state they can be charged with a large current, leading to the increase of the proportion of regenerative braking force. In case of SOC $<10 \%$, the inner resistance of the battery has high values, the result is unsuitable for charging. For SOC $>90 \%$, charging current should be decreased to prevent deposit of Li-Ion.

- Using of regenerative brakes combined with friction brakes could cause wrong force distribution among wheels and axles and as a result stability loss (Crolla, 2009). To prevent front or rear axle lock that will cause vehicle to became unstable, correct force distribution should be applied so that the front and rear begin to slide at the same time. The coefficients for braking force distribution on axles depend on position of mass centre. Also, control strategies for distribution of braking force between wheels of the same axles can be used to achieve straight line stability or cornering behaviour.

\section{Conclusion}

Braking is essential part of driving cycle. Traditional frictional braking represents use of energy to dissipate vehicle's kinetic energy, on the other side on electrical and hybrid vehicles it is possible to convert part of dissipated energy into electrical/chemical energy, which can be used later. Regenerative braking systems can capture between 8 to $25 \%$ of energy (Li Zhe et al., 2016), but this amount highly depends on driving cycle, energy storage type. We also saw that vehicle cannot be equipped only with regenerative braking due to its incapability to bring vehicle in standstill and implement emergency braking.

As regenerative braking looks perspective, braking strategies are proposed to increase its efficiency, vehicle's stability. Based on used types of energy storage systems (supercapacitors, batteries or combined) corresponding braking strategies are suitable.

\section{REFERENCES}

Alexandra von Maier, Electric Power Systems: A Conceptual Introduction (Wiley-IEEE Press), 2006.

David A. Crolla, Automotive Engineering, Powertrain, Chassis System and Vehicle Body, (Elsevier), 2009.

Ehsani M., Gao Y., Gay S.E., Modern Electric, Hybrid Electric and Fuel Cell Vehicles, (Boca Raton, London, New York Washington: CRC Press, 2005. 
Krzysztof Popiołek, Tomasz Detka, Karol Żebrowski, Konrad Małek, Analysis of Regenerative Braking Strategies (Przemysłowy Instytut Motoryzacji, Zakład Elektromobilności, Politechnika Warszawska, Instytut Elektrotechniki Teoretycznej i Systemów Informacyjno-Pomiarowych), 2019.

Li Zhe, Zheng Ling, Ren Yue, Yang Wei, Li Yinong, Gao Feng, Li Yusheng, Xiong Zhoubin, A Control Strategy of Regenerative Braking System for Intelligent Vehicle, (State Key Laboratory of Mechanical Transmission, College of Automotive Engineering, Chongqing University, Chongqing 400044 Changan Automotive Engineering Institute, Chongqing 401120), 2016.

Stephen Champman, Electric Machinery Fundamentals (McGraw-Hill Education), 2011.

Tao Liu, Jincheng Zheng, Yongmao Su, Jinghui Zhao, A Study on Control Strategy of Regenerative Braking in the Hydraulic Hybrid Vehicle Based on ECE Regulations, (School of Automobile Engineering, Harbin Institute of Technology, Weihai 264209, China), 2013.

Xiao B., Lu H., Wang H., Ruan J., Zhang N., Enhanced Regenerative Braking Strategies for Electric Vehicles: Dynamic Performance and Potential Analysis. (Energies,11 (2017), nr.10, 1875), 2017.

\section{STUDIUL FRÂNEI REGENERATIVE LA AUTOVEHICULE ELECTRICE ȘI HIBRIDE}

\section{(Rezumat)}

Sistemele de frânare cu frâna regenerativă devin tot mai populare în contextul creșterii producției de autovehicule electrice și hibride. Acest lucru impune o concurență între producători pentru a oferi un sistem cu eficiență maximă. În această lucrare sunt prezentate pe scurt mijloacele de recuperare a energiei cinetice pe parcursul frânării, urmând să ne axăm pe sisteme de frânare regenerativă cu conversie în energie electrică (super condensatoare) sau chimică (baterii). Alegerea strategiei de control a frânei regenerative și frânei hidraulice joacă un rol important în cadrul acestor sisteme pentru a obține eficiența maximă, funcție de configurație sistemului de propulsie (electric, hibrid, cu una sau două punți motoare). 